\title{
PENDIDIKAN POLITIK BAGI MASYARAKAT SEBAGAI PENYELENGGARA PEMILU TINGKAT AD HOC
}

\author{
Istikharah 1), Asrinaldi ${ }^{2)}$ \\ 1,2,) Megister Kosentrasi Tata Kelola Pemilu Fakultas Ilmu Sosial Dan Ilmu Politik \\ Universitas Andalas, Padang, Indonesia
}

\begin{abstract}
Abstrak
Penelitian ini berawal dari masih rendahnya pengetahuan politik masyarata. Masyarakat yang menjadi penyelenggara pemilu secara otomatis juga memiliki pengetahuan politik yang masih rendah. Dilihat dari fungsi partai politik yang memiliki tugas memberikan pendidikan Pendidikan politik bagi masyarakat masih belum maksimal. Maka dirasa perlu untuk memberikan pendidikan politik bagi masyarakat guna menambah kesadaran masyarakat tentang politik. Bahwa politik bukan hanya sekedar untuk mendapatkan kekuasaan, politik mengajarkan kita bagaimana proses demokrasi yang baik dan sesuai dengan peraturan.
\end{abstract}

Kata Kunci: Pendidikan Politik, Penyelenggara Pemilu Ad Hoc.

*Correspondence Address : istikharah84@gmail.com DOI : $10.31604 /$ jips.v6i2.2019.314-328

(c)2019 Fakultas Keguruan \& Ilmu Pendidikan UM-Tapanuli Selatan 


\section{PENDAHULUAN}

Penyelenggara pemilu di tingkat ad hoc merupakan perpanjangan tangan dari KPU (Komisi Pemilihan Umum). Penitia pemungutan suara (PPS) adalah pelaksana pemilihan di tingkat kelurahan/desa/ nagari.

PPS diharapkan adalah orangorang yang memahami tugas dan fungsi sebagai penyelenggara. Selain itu PPS juga diharapkan memahami prinsipprinsi yang harus dimiliki oleh seorang penyelenggara, sebagaimana yang dikemukan oleh Alan Wall, dkk dalam IDEA (2014) yaitu : 1) independensi, 2) imparsialitas, 3) intgeritas, 4)transparansi, 5) efesiensi, profesionalisme dan 7) berorientasi pelayanan.

Namun dalam pelaksanannya masih banyak PPS yang tidak mengerti dan mengetahui prinsip-prinip tersebut. Hal ini disebabkan karena, selama masa kerja PPS tidak pernah diajarkan atau di Bimtek (bimbingan teknis) tentang prinsip-prinsip seorang penyelenggara. Hal ini dapat dilihat dari masih banyaknya pelanggaran yang dilakukan oleh PPS.

Pelanggaran yang dilakukan oleh PPS ini terkait dengan etika seorang penyelenggara. Salah satu contoh pelanggaran yang dilakukan oleh PPS adalah PPS di Kabupaten Sijunjung pada saat pemilihan kepala daerah dan wakil kepala daerah tahun 2015, menunjukkan dukungannya kepada salah satu pasangan calon bupati dan wakil bupati sijunjung di media sossial. Ini disebabkan karena PPS tersebut tidak mengetahui prinsip-prinsip seorang penyelenggara pemilu.

Seharusnya seorang penyelenggara ad hoc juga diberikan pendidikan politik. pemahaman dan realitas pendidikan politik sering dibatasi dengan pemahaman tunggal, yaitu formal politik. Misalnya, politik dipahami dengan kekuasaan, pemerintahan, negara, konstitusi, partai politik, dan pemilihan umum. Kesadaran politik warga bangsa diwujudkan dengan keterlibatan atau partisipasi mereka dalam pemilihan anggota wakil rakyat dan eksekutif. Menurut Fraser (1999), pandangan orang tentang politik dibagi dalam tiga kelompok. Pertama, politik identik dengan kekuasaan. Kelompok ini lebih menitikberatkan pada analisis kekuasaan atau sistem pemerintahan.

Guna merubah pandangan tersebut maka dirasa perlu untuk memberikan pendidikan politik kepada penyelenggara pemilihan di tingkat ad hoc. Hal ini dimaksudkan untuk lebih membuka pemikiran penyelenggara 
pemilu di tinngkat ad hoc tentang bagaimana pembelajaran tentang berdemokrasi.

Pendidikan dan politik merupakan dua hal yang berbeda, namun memiliki tujuan utama yang saling medukung satu sama lain. Keduanya bahumembahu dalam proses pembentukan karakteristik masyarakat di suatu negara. Lebih dari itu, keduanya satu sama lain saling menunjang dan saling mengisi.Pendidikan menyangkut proses transmisi ilmu pengetahuan dan budaya, serta perkembangan keterampilan dan pelatihan yang membawa perubahan pada diri individu terdidik (Sudiarja, 2006:413). Sedangkan politikberkenaan dengan praktik kekuasaan, pengaruh dan otoritas yang berkenaan dengan pembuatan keputusan-keputusan otoritatif tentang alokasi nilai-nilai dan sumber daya. Karena keduanya sarat dengan proses pengalokasian dan pendistribusiannilai-nilai dalam masyarakat, maka tidaklah sulit untuk memahami bahwa pendidikan dan politik adalah dua perangkat aktivitas yang akan terus saling terkait dan berinteraksi.

Pendidikan politik dalam tulisan ini dipahami sebagai perbuatan memberi latihan, ajaran, serta bimbingan untuk mengembangkan kapasitas dan potensi diri manusia, melalui proses dialogik yang dilakukan dengan suka rela antara pemberi dan penerima pesan secara rutin, sehingga para penerima pesan dapat memiliki kesadaran berdemokrasi dalam kehidupan bernegara. Hal ini dimaksudkan agar dapat mewujudkan kesadaran dan partisipasi berdemokrasi dalam kehidupan bernegara.

Definisi pendidikan politik ini mengandung tiga anasir penting, yakni: Pertama, adanya perbuatan memberi latihan, ajaran, serta bimbingan untuk mengembangkan kapasitas dan potensi diri manusia. Kedua, perbuatan di maksud harus melalui proses dialogik yang dilakukan dengan suka rela antara pemberi dan penerima pesan secara rutin. Ketiga, perbuatan tersebut ditujukan untuk para penerima pesan dapat memiliki kesadaran berdemokrasi dalam kehidupan bernegara.

\section{METODE PENELITIAN}

Dalam penelitian ini penulis menggunakan metode studi kepustakaan. Dalam setiap penilitian studi kepustakaan sangat diperlukan, namun dalam studi lapangan riset kepustakaan hanya digunakan sebagai langkah awal untuk menyiapkan penelitian. Sedangkan dalam studi pustaka, penelusuran pustaka lebih 
kepada pemanfaatan sumber perpustakaan untuk memperolah data untuk penelitian. Tegasnya studi pustaka membatasi kegiatannya hanya pada bahan-bahan koleksi perpustakaan saja tanpa memerlukan riset lapangan.

Ada tiga alasan kenapa peneliti menggunakan studi pustaka dalam risetnya. Pertama, karena persoalan penelitian tersebut hanya bisa dijawab lewat penelitian pustaka dan sebaliknya tidak mungkin mengharapkan riset lapangan. Kedua, studi pustaka diperlukan sebagai salah satu tahap tersendiri, yaitu studi pendahuluan untuk memahami lebih dalam gejala baru yang tengah berkembang di lapangan atau dalam masyarakat. Ketiga, data pustaka menjadi pilihan yang penting untuk menjawab persoalan penelitian. Dari data empirik atau informasi yang telah dikumpulkan orang lain, baik berupa laporan hasil penelitian, atau laporan-laporan resmi, buku-buku yang tersimpan diperpustakaan tetap dapat dipergunakan oleh periset kepustakaan. Dalam kasus tertentu data lapangan diperkirakan tidak cukup signifikan untuk menjawab pertanyaan penilitian yang akan dilakukan.(Mestika Zed, 2004:2).

\section{HASIL DAN PEMBAHASAN}

Ramlan Surbakti dalam bukunya yang berjudul memahami ilmu politik (1999:117) mengemukakan bahwa pendidikan politik dan sosialisasi politik memiliki kesamaan dalam istilah. Dalam bahasa Inggris kedua istilah ini memang sering disamakan. Istilah political sosialization jika diartikan secara harfiah ke dalam bahasa Indonesia akan bermakna sosialisasi politik. Oleh karena itu, dengan menggunakan istilah politicalsosialization banyak yang mensinonimkan istilah pendidikan politik dengan istilah Sosialisasi Politik, karena keduanya memiliki makna yang hampir sama. Dengan kata lain, sosialisasi politik adalah pendidikan politik dalam arti sempit.Melalui proses sosialisasi politik para anggota masyarakat dapat memperoleh sikap dan orientasi terhadap kehidupan politik yang berlangsung dalam masyarakat. Atau dengan kata lain, di dalam pendidikan politik terjadi proses pembelajaran dan pemahaman tentang hak, kewajiban, dan tanggung jawab setiap warga negara dalam kehidupan berbangsa dan bernegara.

Pendidikan politik dapat dikatakan sebagai media penyampaian 
konsep politik yang memiliki tujuan akhir untuk membuat warga negara menjadi lebih melek politik. Warga negara yang melek politik adalah warga negara yang sadar akan hak dan kewajiban sehingga dapat ikut serta dalam kehidupan berbangsa dan hernegara dalam setiap proses pembangunan. Pendidikan politik diperlukan keberadaannya terutama untuk mendidik generasi muda saat ini yang nantinya akan menjadi generasi penerus bangsa.

Menurut Rusadi Kantaprawira (2004:55). Pendidikan politik yaitu untuk meningkatkan pengetahuan rakyat agar mereka dapat berpartisipasi secara maksimal dalam sistem politiknya. Sesuai paham kedaulatan rakyat atau demokrasi, rakyat harus mampu menjalankan tugas partisipasi. bentuk-bentuk

pendidikan politik dapat dilakukan melalui:

a) Bahan bacaan seperti surat kabar, majalah, dan lain-lain bentuk publikasi massa yang biasa membentuk pendapat umum

b) Siaran radio dan televisi serta film (audio visual media).

c) Lembaga atau asosiasi dalam masyarakat seperti masjid atau gereja tempat menyampaikan khotbah, dan juga lembaga pendidikan formal ataupun iniformal.

Menurut Surono sebagaimana dikutip Ramdlang Naning (1982:8). Pendidikan politik adalah usaha untuk masyarakat politik, dalam arti mencerdaskan kehidupan politik rakyat, menigkatkan kesadaran warga

terhadap kepekaan dan kesadaran hak,kewajiban dan tanggung jawab terhadap

bangsa dan negara.

Menurut Alfian (1990:245-246). Mengidentifikasi pendidikan politik dalam

arti kata yang longgar yaitu sosialisasi politik adalah bagian langsung dari kehidupan masyarakat sehari-hari. Disenangi ataukah tidak, diketahui ataukah tidak, disadari ataukah tidak, hal itu dialami oleh anggota-anggota masyarakat, baik penguasa ataupun orang awam. Jadi kalau boleh disimpulkan, pendidikan politik (dalam arti kata yang ketat) dapat diartikan usaha yang sadar untuk mengubah proses sosialisasi masyarakat sehinnga mereka memahami dan menghayati betul nilai-nilai politik yang terkandung dalam suatu sistem politik yang ideal yang hendak dibangun. Hasil penghayatan itu akan menghasilkan/melahirkan sikap dan 
tingkah laku politik baru yang mendukung sistem politik yang ideal itu, dan bersamaan dengan itu lahir pula kebudayaan politik baru.

Lewat pendidikan politik juga diharapkan agar dengan jiwa persatuan,kesatuan dan saling ketergantungan yang sangat erat kita mampu menanggulangi segala ancaman dan serbuan kekuatan-kekuatan atau pengaruh-pengaruh dari luar yang ingin mengancam.

Pemahaman dan manifestasi pendidikan politik akan sangat dipengaruhi cara pandang seseorang atau kelompok tentang politik. Dalam realitas, pemahaman dan realitas pendidikan politik sering dibatasi dengan pemahaman tunggal, yaitu formal politik. Misalnya, politik dipahami dengan kekuasaan, pemerintahan, negara, konstitusi, partai politik, dan pemilihan umum. Kesadaran politik warga bangsa diwujudkan dengan keterlibatan atau partisipasi mereka dalam pemilihan anggota wakil rakyat dan eksekutif.

\section{Menurut Fraser} pandangan orang tentang politik dibagi dalam tiga kelompok. Pertama, politik identik dengan kekuasaan. Kelompok ini lebih menitikberatkan pada analisis kekuasaan atau sistem pemerintahan.
Pendidikan politik dipahami dalam pengertian pembelajaran demokrasi, yakni berkaitan dengan caracara yang absah (demokratis) untuk menyelematkan, menata, memengaruhi kekuasaan politik (political power), termasuk juga beroposisi dengan kekuasaan.

Kedua, politik ialah sirkulasi kekuasaan (politik) atau kekuatan ekonomi. Untuk mendapatkan kekuasaan (politik atau ekonomi), kita tidak dapat menghindar diri dari perebutan (kompetisi). Untuk itu, aturan main berpolitik perlu ditegakkan sehingga konflik yang muncul sebagai akibat kompetisi atau perebutan kekuasaan dapat dikelola dan menjadi kekuatan untuk membuat kehidupan dinamis.

\section{Konsep dan misi}

Pendidikan politik sering juga disebut pembelajaran politik (political learning) atau sosialisasi politik (political socialization) ialah proses pembentukan serta pengembangan sikap dan perilaku politik.

Pendidikan politik tidak dibatasi dalam pengertian formal politik, seperti keterlibatan dalam kampanye partai politik dan memberikan suara dalam 
pemilihan umum atau pilkada (Adelabu dan Akinsolu: 2009; Orit: 2004).

Pendidikan politik memberikan seseorang pengetahuan dan keterampilan untuk memahami persoalan politik dalam pengertian yang luas, termasuk pengakuan dan penghargaan terhadap keragaman nilai sosial politik yang dianut seseorang dan kelompok (komunitas).

Pendidikan politik menumbuhkan keterlibatan seseorang dalam diskusi politik dengan banyak orang; melakukan deliberasi tentang persoalan-persoalan kehidupan lainnya (luas). Pendidikan politik juga membuat seseorang mampu memberi pengaruh terhadap orang-orang tentang persoalan-persoalan politik (Adelabu dan Akinsolu: 2009; Clarke: 2007; Davies: 2005).

Dari pengertian tersebut, ada tiga misi atau fungsi utama pendidikan politik. Pertama, pendidikan politik ialah revitalisasi pemahaman tentang politik. Pendidikan politik bukan mengajarkan peserta didik tentang berapa kursi di badan legislatif, melainkan memberi pemahaman atau kesadaran kepada publik bahwa fungsi-fungsi kekuasaan itu sebagai a constitutive force, bagaimana pembagian kekuasaan, pertarungan kekuasan, serta bagaimana kekuasaan dimanfaatkan wakil rakyat dan untuk siapa (Ruitenberg, na; Dumas dan Dumas: 1996; Davies: 2005).

Kedua, pendidikan politik ialah pendidikan emosi politik (educating political emotion). Dalam hal ini, emosi bukan dalam pegertian private domain, yaitu perasaan pribadi atau kelompok yang didasarkan pada konsepsi identitas diri. Namun, emosi dipahami dalam konteks tatanan sosial politik atau kolektif politik, yaitu pandangan terhadap hubungan sosial yang hegemonik.

Dari fungsi ini, pendidikan politik ialah menumbuhkan dan mengembangkan rasa solidaritas, komitmen terhadap kelompok masyarakat yang tidak berdaya (tertindas), dan (meningkatkan) kemampuan melawan ketidakadilan.

Ketiga, pendidikan politik ialah mengembangan melek politik atau kesadaran politik (political literacy). Melek politik mempunyai hubungan dengan keterampilan, isu dan aksi penerapan politik yang demokratis, serta pendidikan global, yaitu pembelajaran afektif dan pendekatan holistis tentang isu-isu dunia. Pendidikan kewargabangsaan yang 
berkaitan dengan kesukarelaan untuk berbuat sesuatu di masyarakat (Davies: 2005), kemampuan seseorang membaca landscape politik dalam konfigurasi pada era kini dan masa lalu (historisitas). Dalam pembelajaran politik, peserta didik didorong (enabling) memahami tatanan sosial dan politik melalui, misalnya, deliberasi tentang kebebasan, persamaan, dan relasi sosial yang hegemonik.

Melek politik ialah kemampuan memahami konflik kepentingan dan cita-cita dari tiap-tiap kelompok. Sikapsikap yang mencirikan melek politik dan demokrasi substantif, seperti menghargai kebebasan, persamaan, toleransi, menghargai keyakinan, dan pemikiran orang lain (Clarke, 2007).

Pendidikan politik

\section{Aspek-aspek Pendidikan Politik} (kognitif, afektif, dan psikomotor)

Aspek-aspek pendidikan politik merupakan salah satu substansi kajian pendidikan politik yang didalami di lembaga pendidikan tinggi terutama lembaga pendidikan tenaga kependidikan. Aspek-aspek atau ranah pendidikan politik ini terdiri atas tiga aspek, yaitu aspek kognitif, afektif, dan psikomotor. Ketiga ranah atau aspek pendidikan politik itu dijelaskan sebagai berikut.

\section{Aspek Kognitif Pendidikan Politik:} Membangun Pengetahuan Politik

\section{Warga Negara}

Salah satu aspek yang menjadi tujuan pendidikan politik adalah aspek kofnitif yang arahnya adalah membangunan pengetahuan politik warga negara (civic knowledge). Pengetahuan dan pemahaman warga negara terhadap konsep-konsep politik dasar tertentu menjadi sangat penting untuk dibangun karena tanpa kesadaran politik yang kritis tidak mungkin ditumbuhkan. Padahal, kesadaran politik-kritis merupakan syarat penting bagi suatu partisipasi warga negara yang otonom.

Ada beberapa persoalan pokok yang seharusnya dipahami dan diketahui oleh setiap warga negara dalam kerangka pembangunan aspek kognitif ini. Persoalan-persoalah tersebut, di antaranya adalah (1) Demokrasi dan hak-hak warga negara; (2) Kedaulatan Rakyat; (3) Sistem kelembagaan negara; (4) Sistem Politik; dan (5) Pemilihan Umum, dan sebagainya19. 
2. Aspek Afektif Pendidikan Politik:

Membangun Karakter dan

Keberpihakan Warga Negara

dalam Kehidupan Demokrasi

Pendidikan adalah proses mengenalkan dan menanamkan nilainilai tertentu pada seorang warga negara. Nilai-nilai itu disampaikan dan ditanamkan untuk membentuk karakter dan keberpihakan warga negara dalam mengimplementasikan nilai-nilai itu dalam kehidupan seharihari baik kapasitasnya sebagai individu yang bebas otonom maupun sebagai warga negara yang bertanggung jawab20.

\section{Aspek Psikomotor Pendidikan}

Politik: Membangun Kecakapan

\section{Warga Negara}

Kecakapan-kecakapan warga negara meliputi dua kecakapan (keahlian) yaitu (1) kecakapan intelektual yakni kecakapan berpikir kritis dan (2) kecakapan partisipatoris, dalam pendidikan politik mencakup tiga keahlian yakni keahlian berinteraksi (interacting), keahlian memantau (monitoring) isu publik, dan keahlian mempengaruhi (influencing) kebijakan publik sebagaimana dijelaskan oleh A. Ubaidillah dan M.
Noer Khoiron. Untuk lebih jelasnya, berikut ini diuraikan satu per satu.

\section{Kecakapan Intelektual:}

\section{Kecakapan Berpikir Kritis}

Kecakapan intelektual adalah kecakapan berpikir kritis. Kecakapan intelektual warga negara dalam melihat berbagai persoalan politik dan pemerintahan tidak dapat dipisahkan dalam materi pendidikan politik. Kemampuan warga negara untuk memikirkan isu politik secara kritis yaitu memahami isu itu, berikut sejarahnya, keterkaitannya dengan masa kini, serta merangkainya dengan piranti-piranti intelektual untuk membuat berbagai pertimbangan yang akan bermanfaat dalam menangani isu tersebut.

Unsur-unsur dari kecakapan intelektual (berpikir kritis) meliputi: kemampuan mendengar, kemampuan mengidentifikasi dan mendeskripsikan persoalan, kemampuan menganalisis, dan kemampuan melakukan suatu evaluasi isu-isu publik, sebagaimana dijelaskan oleh A. Ubaidillah26 dan M. Noer Khoiron27 sebagai berikut.

\section{1) Kemampuan mendengar}

Kemampuan untuk mendengar dengan penuh perhatian dan penghargaan terhadap 
pembicaraan atau pendapat orang lain merupakan kunci bagi terbentuknya kecakapan intelektual warga negara. Seorang warga negara tidak akan pernah menjadi bagian penting dari sebuah kelompok atau masyarakat jika ia tidak mampu membangun kebiasaan yang baik dalam mendengarkan pendapat orang lain.

\section{2) Kemampuan mengidentifikasi} dan mendeskripsikan persoalan

Warga negara yang berpikir kritis mampu mengidentifikasi berbagai hal yang nyata atau tidak nyata. Mampu mengidentifikasi berarti dapat membedakan satu persoalan atau fakta dari yang lain, mengklasifikasi persoalan dan menentukan asal usulnya. Sedangkan kemampuan mendeskripsikan persoalan yang nyata dan tidak nyata adalah kemampuan untuk menjelaskan objek, proses, institusi, fungsi, kegunaan, alat dan tujuan, serta kualitas-kualitas dari objek yang dideskripsikan. Dalam hal ini warga negara harus bisa menjelaskan fungsi dan proses politik secara umum, seperti partisipasi, pengambilan keputusan, pembuatan peraturan/undang-undang, dan sebagainya.

\section{3) Kemampuan mengeksplanasi}

\section{dan melakukan analisis}

Kemampuan mengeksplanasi dan melakukan analisis maksudnya kemampuan untuk mengidentifikasi, mendeskripsikan, mengklarifikasi atau menafsirkan suatu persoalan. Yang dieksplanasi adalah sebab dari suatu peristiwa, makna atau signifikansi dari peristiwa atau gagasan-gagasan, alasan-alasan yang menjadi dasar perilaku politik atau posisi-posisi. Warga negara seharusnya mampu menjelaskan bagaimana sistem politik bekerja, dan di mana posisinya dalam sistem itu. Kemampuan menganalisis memungkinkan warga negara untuk membedakan antara fakta dan opini atau antara alat dan tujuan politik. 
4) Kemampuan mengevaluasi

Kemampuan Evaluasi berarti kemampuan menggunakan kriteria-kriteria atau standar tertentu untuk: menilai kekuatan dan kelemahan isu-isu publik, tujuan yang dicapai, dan alat-alat yang dianjurkan untuk mencapai tujuan-tujuan politik. Evaluasi dibutuhkan untuk menilai isu-isu publik dan mendiskusikan kebutuhan warga negara di tengah isu publik, termasuk apa konsekuensi yang akan diterima oleh warga negara dari berkembangnya isu publik.

\section{a. Keacakapan Partisipatoris}

Pendidikan politik untuk warga negara (civic education) tidak hanya sekadar mengusik kesadaran kritis dan jiwa demokrat serta sikap keberpihakan warga negara. Aspek-aspek tersebut merupakan muara yang berujung pada tindak keterlibatan atau partisipasi warga negara yang efektif dan bertanggung jawab untuk memperbaiki kualitas kehidupan sosial dan politiknya. Untuk dapat berpartisipasi dengan efektif dan bertanggung jawab serta dilandasi dengan pengetahuan yang cukup, warga negara perlu memiliki kemampuan tertentu untuk berpartisipasi atau bisa disebut sebagai kecakapan partisipatoris (political skill). Keterlibatan yang tidak efektif, apalagi ketiadaan partisipasi, akan mengakibatkan perubahan harkat kehidupan yang tidak signifikan bahkan mungkin tidak ada artinya sama sekali.

Dalam konteks pendidikan politik, kecakapan partisipatoris mencakup tiga kecakapan atau keahlian sebagaimana dijelaskan oleh A. Ubaidillah28 dan M. Noer Khoiron29 sebagai berikut.

\section{Keahlian berinteraksi (interacting)}

Keahlian berinterkasi merupakan kemampuan yang diperlukan oleh warga negara untuk berkomunikasi dan bekerja sama dengan warga negara yang lain. Mampu berinteraksi berarti mampu untuk bertanya, menjawab, dan berbicara dengan baik; membangun koalisi; dan mengelola konflik dengan baik. Keahlian berinteraksi meliputikeahlian: (a) keahlian 
mendengarkan dengan penuh perhatian; (b) bertanya dengan efektif; (c) mengutarakan pikiran dan perasaan; dan (d) mengelola konflik melalui mediasi, kompromi, dan kesepakatan.

\section{Keahlian memantau (monitoring) isu publik}

Keahlian memantau persoalan politik dan pe-merintah mengacu kepada kemampuan warga negara untuk mengamati dan memahami penanganan persoalan yang terkait dengan proses politik dan pemerintahan. Dengan kata lain, warga negara mampu mengambil bagian dan sekaligus menjadi pengawas atau "watch dog" bagi proses politik atau pemerintahan. Keahlian memantau isu politik meliputi kemampuan untuk: (a) meriset isu publik melalui studi pustaka hingga studi lapangan; (b) menghadiri pertemuan-pertemuan publik; dan (c) mengamati proses peradilan dan mekanisme kerja sistem hukum.

\section{Keahlian mempengaruhi (influencing) kebijakan publik}

Keahlian untuk mempengaruhi kebijakan publik mengacu kepada kemampuan warga negara untuk mempengaruhi proses politik dan pemerintahan, baik proses pemerintahan yang bersifat formal maupun informal di masyarakat, termasuk proses-proses politik di level yang paling bawah seperti di desa. Keahlian mempengaruhi kebijakan publik meliputi kemampuan untuk: (a) membuat petisi, (b) berbicara di depan umum, (c) bersaksi di depan badanbadan publik, (d) terlibat dalam kelompok advokasi ad-hoc, dan (e) membangun aliansi.

Warga negara yang cerdas dan baik juga mampu melibatkan diri atau partisipatif dalam berbagai aspek kehidupan bermasyarakat, berbangsa dan bernegara. Warga negara partisipatif adalah warga negara yang senantiasa melibatkan diri atau ikut serta dalam berbagai kegiatan. Warga negara partisipatif dalam berbagai kegiatan kehidupan bermasyarakat, berbangsa dan bernegara pada berbagai aspek kehidupan nasional; meliputi partisipasi pada aspek politik, ekonomi, sosial, budaya, dan partisipasi pada aspek yang lainnya.

Semua penjelasan di atas menunjukkan kualitas warga negara yang dapat diandalkan yaitu warga negara yang cerdas dan baik, yang memahami akan hak dan kewajibannya sebagai warga negara dalam kaitannya atau hubungannya dengan negara dan 
lingkungannya. Warga negara yang dapat diandalkan merupakan warga negara yang memiliki kopetensi civic knowledge, civic skills, dan civic disposition serta warga negara yang memiliki kecerdasan moral sebagaimana dijelaskan oleh Thomas Lickona34, yaitu moral knowing, moral feeling, dan moral behavioral). Dimensidimensi yang termasuk dalam kecerdasan moral berupa moral knowing yang akan mengisi ranah kognitif adalah kesadaran moral (moral awareness), pengetahuan tentang nilainilai moral (knowing moral values), penentuan sudut pandang (perspective taking), logika moral (moral reasoning), keberanian mengambil sikap (decision making), dan pengenalan diri (self knowledge). Dimensi moral feeling merupakan penguatan aspek emosi untuk menjadi manusia berkarakter. Penguatan ini berkaitan dengan bentukbentuk sikap yang harus dirasakan oleh peserta didik, yaitu kesadaran akan jati diri (conscience), percaya diri (self esteem), kepekaan terhadap derita orang lain (emphaty), cinta kebenaran (loving the good), pengendalian diri (self control), kerendahan hati (humility). Serta dimensi moral action merupakan perbuatan atau tindakan moral yang merupakan hasil (outcome) dari dua komponen karakter lainnya. Untuk memahami apa yang mendorong seseorang dalam perbuatan yang baik (act morally) maka harus dilihat tiga aspek lain dari karakter yaitu kompetensi (competence), keinginan (will), dan kebiasaan (habit).

\section{KESIMPULAN DAN SARAN}

Kajian pendidikan politik merupakan kajian yang menunjukkan usaha dalam meningkatkan dan memantapkan pemahaman dan kesadaran politik, pemahaman dan kesadaran kehidupan berbangsa dan bernegara oleh warga negara dari generasi yang satu ke generasi berikutnya. Pendidikan politik dalam negara yang demokratis memberikan konstribusi besar dalam mewujudkan demokrasi yang semakin dewasa dan bermartabat serta beradab. Salah kajian pendidikan pendidikan politik, di mana warga negara perlu meningkatkan terus menerus kompetensinya adalah yang berkaitan dengan aspek-aspek pendidikan politik. Aspek-aspek pendidikan politik yang perlu selalu ditingkatkan kompetensinya oleh warga negara terdiri atas: (1) aspek kognitif merupakan aspek yang memberikan kontribusi dalam membangun pengetahuan politik warga negara; (2) 
aspek afektif yang memberikan

kontribusi dalam membangun karakter dan keberpihakan warga negara dalam kehidupan demokrasi; dan (3) aspek psikomotor yang memberikan kontribusi dalam membangun kecakapan warga negara.

Untuk mengembangkan kehidupan demokrasi di Indonesia dan mempertahankan kelangsungan hidup suatu bangsa dan negara Indonesia sangat membutuhkan warga negara yang cerdas dan baik (smart and good citizenship), warga negara yang dapat diandalkan oleh bangsa dan negara, yaitu warga negara yang memahami akan hak dan kewajibannya sebagai warga negara dalam kaitannya atau hubungannya dengan negara dan lingkungannya. Untuk meningkatkan pengembangan kompetensi aspek-aspek pendidikan politik, setiap warga negara diharapkan memiliki dan selalu meningkatkan kompetensi civic knowledge, civic skills, dan civic disposition serta mewujudkan warga negara yang bermoral, yang memiliki kecerdasan moral knowing, moral feeling, moral behavioral.

\section{Daftar Pustaka}

Affandi, Idrus. (2011). Pendidikan Politik: mengefektifkan Organisasi Pemuda Melaksanakan Pendidikan Politik
Pancasila dan UUD 1945. Bandung: Universitas Pendidikan Indonesia.

Alfian. (1986). Pemikiran dan Perubahan Politik. Jakarata: Gramedia.

Amirmachmud. (1987). Pembangunan Politik Dalam Negeri. Jakarta: Gramedia.

Balla, John dan Ramadhan, (1999). Panduan Pendidikan Politik untuk Fasilitator. Yogyakarta: Kerjasama PACT dan Insist.

Betni H. Purba, Beti H, dkk. (2012). Buku Pedoman Pendidikan Politik. Jakarta: Badan Penelitian dan Pengembangan HAM, Kementerian Hukum dan HAM Republik Indonesia.

Branson, Margaret S., dkk. (1999). Belajar Civic Education dari Amerika. Yogyakarta: LKiS.

Fakih, Mansour, dkk., (1999). Panduan Pendidikan Politik untuk Rakyat. Yogyakarta: Kerjasama PACT dan Insist.

Handoyo, Eko dan Lestari, Puji. (2017). Pendidikan Politik. Yogyakarta: Pohon Cahaya.

Kartono, Kartini. (2009). Pendidikan Politik sebagai Bagian dari Pendidikan Orang Dewasa. Bandung. Mandar Maju.

Khoiron, . Nur, dkk. (1999). Pendidikan Politik bagi Warga Negara (Tawaran Operasional dan Kerangka Kerja). Yogyakarta: LKiS.

Lickona, Thomas. (2013). Educating for Character: Mendidik untuk Membentuk Karakter, Bagaimana Sekolah dapat Memberikan Pendidikan tentang Sikap Hormat dan Bertanggung Jawab. Jakarta: Bumi Aksara.

Mahardika, Timur. (2001). Pendidikan Politik Pemberdayaan Desa Panduan

Praktisi: Yogyakarta: Lapera Pustaka Utama. Masyitoh, Iin Siti. (2008).

Memahami Pendidikan Kewarganegaraan. Bandung: UPI Bandung. 
Naning, Ramdlon. (1982). Pendidikan Politik dan Regenerasi. Yogyakarta: Liberty.

Sumantri, Endang, dkk. (2003). Pendidikan Politik. Jakarta: Universitas Terbuka.

Sunatra. (2016). Pendidikan Politik Kewarganegaraan. Bandung: LeKKaS

Surbakti, Ramlan. (1984). Dasar-Dasar Ilmu Politik. Surabaya: Universitas Airlangga.

Ubaidillah, A. dkk. (2000). Pendidikan Kewargaan (Civic Education), Demokrasi, HAM, dan Masyarakat Madani. Jakarta: IAIN Syarif Hidayatullah.

Wahab, A. Azis. (1996). Politik Pendidikan dan Pendidikan Politik: Model Pendidikan Kewarganegaraan Indonesia Menuju Warga Negara Global. Bandung: IKIP Bandung.

Winataputra, Udin S. dan Budimansyah, Dasim. (2007). Civic Education: Landasan, Bahan Ajar, dan Kultural Kelas. Bandung: SPS UPI Bandung.. 